\title{
Analysis of the relationship between insulin-like growth factor 1 receptor gene polymorphisms in Montbeliarde cows and the birth weight of their calves
}

\author{
Małgorzata Szewczuk
}

\author{
The West Pomeranian University of Technology, Department of Ruminant Science, \\ Laboratory of Biostatistics, Szczecin, Poland \\ Received May 19, 2015 \\ Accepted February 10, 2016
}

\begin{abstract}
Montbeliarde is a cattle breed of combined milk and meat performance type, which unlike the other breeds is characterized by several positive features, such as better health, high resistance to mastitis, calving ease and good weight gain. The study involved a population of 163 Montbeliarde cows. In view of the substantial role of the IGF-I/IGF-IR system in growth and development, the aim of this study was to show an association between insulin-like growth factor 1 receptor gene polymorphisms in Montbeliarde cows and birth weight of their offspring. Three single nucleotide polymorphisms within the $I G F 1 R$ gene were analyzed using PCR-RFLP or ACRS-PCR methods. The frequencies of the most common genotypes were as follows: CC 0.90 (IGF1R/TaiI), GG $0.77(I G F 1 R / M s p \mathrm{I})$ and $G G 0.58(I G F 1 R / T a q \mathrm{I})$. A total of 14 combinations was compared, from which due to the low frequency $(\mathrm{n}<10)$ only 4 were used for calculations. In the analysed herd, the mean body weight of calves regardless of the calving order was always the highest in animals with maternal $C C / G G / A A$ combined genotype. This observation was confirmed statistically both for the individual genotypes as well as in the case of cows carrying such a combination at the same time $(P<0.01)$. Therefore, IGF1R may be considered as a promising candidate gene for the identification of molecular markers predicting meat quality in cattle.
\end{abstract}

Body weight, cattle, single nucleotide polymorphism, tyrosine kinase

In recent years, the French Montbeliarde breed originating from the region of FrancheComte is gaining considerable interest among international breeders. This breed is increasingly imported because of better health, high resistance to mastitis, calving ease, good weight gain, high slaughter yield, good fertility, and lactation persistence (Borkowska and Januś 2010). Although until now only few works have been published on the acclimatization of this cattle in Polish conditions, the studies and the results of milk performance evaluation indicated a good and quick acclimatization of these animals to domestic conditions, which may serve as an alternative for farms where the conditions do not guarantee profitability of the Holstein-Friesian breed (Trela 2003; Gołębiewski and Brzozowski 2008). An increase in the number of active population of these cows in Poland has been observed since 1995 (the first import of cows of the breed, opening of the herd books in 2001). For example, the active population of Montbeliarde cows in Poland is relatively small, but steadily growing and now it counts 2,428 animals. The milk yield of this breed amounts to $7,224 \mathrm{~kg}$ of milk with a fat content and protein content of $4.03 \%$ and $3.50 \%$, respectively (PFCB and DF 2014).

In an era of significant technological progress, the detection of single nucleotide polymorphisms (SNPs) became the basis of large research projects, involving the whole genome screenings using species-specific microarrays (Pertoldi et al. 2014). When examining the characteristics of milk performance, quite large importance is attached to the genes encoding proteins of the so-called somatotrophic axis (e.g., the growth hormone - GH and its receptor - GHR, insulin-like growth factor I - IGF-I, prolactin - PRL and

Address for correspondence:

Dr. Małgorzata Szewczuk

Laboratory of Biostatistics

Department of Ruminant Science

The West Pomeranian University of Technology

Judyma 10, 71-460 Szczecin, Poland

Phone: 091-449-6802

E-mail: malgorzata.szewczuk@zut.edu.pl; szewczukgosia@gmail.com

http://actavet.vfu.cz/ 
transcription factor - STAT5) (Macias and Hinck 2012). It is believed that the action of these genes can significantly influence the modification of composition and quantity of milk produced. Insulin like growth factor I receptor (IGF-IR) is also worthy of interest, as it is the main transducer of IGF-I signalling to the target cell and may be a perfect candidate to serve as a marker gene of cattle performance traits. Although numerous genome scans have now been performed in dairy cattle for milk production traits, there are relatively few reports that have examined meat traits (Casas et al. 2003; Kim et al. 2003), especially the $I G F 1$ region on BTA5 and the IGF1R region on BTA21. Therefore, IGF1R may be considered as a promising candidate gene for the identification of molecular markers predicting meat performance in cattle.

With the exception of the $I G F 1$ gene, detailed studies have not been performed on the effects of newly discovered mutations in other genes encoding components of the IGF-I system in connection with the birth weight of calves, particularly of breeds of combined milk and meat performance type, such as Montbeliarde. The aim of this study was to show an association between insulin-like growth factor 1 receptor gene polymorphisms in Montbeliarde cows and the birth weight of their offspring.

\section{Materials and Methods}

The study included Montbeliarde cattle imported from the Czech Republic (163 animals), which were kept in 2008-2014 at one of the farms in the West Pomeranian Province in Poland. Data on the calves' weights are derived from the breeding farm documentation (heifers - cows' cards). In the analysed herd, cows were kept in the free-stall system and fed standardized ration in the Total Mixed Ration (TMR) system, divided into technology groups depending on the period of lactation and milk yield. Calves were weighed and their birth weight was recorded after the first and second calving of cows.

Peripheral blood from the external jugular vein was collected from cows (mothers of calves) into tubes containing EDTA as anticoagulant. MasterPure ${ }^{\mathrm{TM}}$ Genomic DNA Purification Kit (Epicentre Technologies, USA) was used for DNA isolation according to the manufacturer's instructions. IGF1R gene polymorphism was identified using PCR-RFLP method (Restriction Fragment Length Polymorphism) and ACRS-PCR (Amplification Created Restriction Site). The primer sequences are shown in Table 1.

Reaction thermal profile used was as follows: initial denaturation of DNA template at $94{ }^{\circ} \mathrm{C}$ for $5 \mathrm{~min}$, followed by 33 cycles: DNA template denaturation at $94^{\circ} \mathrm{C}$ for $50 \mathrm{~s}$, annealing temperature of primers optimized individually for each pair $\left(I G F 1 R / T a i \mathrm{I}-59.5^{\circ} \mathrm{C}, I G F 1 R / T a q \mathrm{I}-62^{\circ} \mathrm{C}, I G F 1 R / M s p \mathrm{I}-59.5^{\circ} \mathrm{C}\right)$ for $60 \mathrm{~s}$, synthesis of complementary strands at $72{ }^{\circ} \mathrm{C}$ for $50 \mathrm{~s}$ and a final extension at $72{ }^{\circ} \mathrm{C}$ for $7 \mathrm{~min}$. Reaction was performed in a Tpersonal DNA thermal cycler (Biometra, Germany). The PCR products were digested with the restriction enzymes listed in Table $1(3 \mathrm{~h})$. Electrophoresis was performed on 2\% agarose gel containing ethidium bromide in TBE buffer in the presence of pUC19/MspI DNA ladder (Fermentas ${ }^{\mathrm{TM}}$, ABO Poland) at a constant voltage of $120 \mathrm{~V}$ for 30 minutes. The restriction fragments were visualized under UV light using a transilluminator (Vilber Lourmat $^{\mathrm{TM}}$, France) and were subsequently archived.

Statistical analysis of the relationship between genotypes of three loci $(I G F 1 R / \mathrm{e} 7 / \mathrm{Tai}$, IGF $1 R / \mathrm{e} 12 / \mathrm{MspI}$, $I G F 1 R / \mathrm{e} 21 / \operatorname{Taq} \mathrm{I})$ and the birth weight of calves in the first and second calving was carried out using Statistica ${ }^{\mathbb{R}}$ 10.0 PL software based on the general linear model:

Table 1. The primer sequences used for the amplification of selected fragments of the IGF1R gene.

\begin{tabular}{|c|c|c|c|c|c|c|}
\hline Gene & Location SNP & Primer & Primer sequence & Length of the product & Restriction enzyme & Method \\
\hline \multirow{6}{*}{ IGFIR } & exon 7 & IGF1Re7F & 5'ACAGTGTTTGGGTCCTTAGTGG-3 & \multirow{2}{*}{$236 \mathrm{bp}$} & Tail & \multirow{2}{*}{ PCR-RFLP } \\
\hline & rs41961336 & IGF1Re7R & 5'AGGTGATGATGATTCGGTTCTT-3‘ & & $\mathrm{ACGT} /\left(65^{\circ} \mathrm{C}\right)$ & \\
\hline & exon 12 & IGF1Re12F & 5'-TTCTTGCCTGTTTCAATTGTTG-3' & \multirow{2}{*}{$164 \mathrm{bp}$} & MspI & \multirow{2}{*}{ PCR-RFLP } \\
\hline & rs41640706 & IGF1Re12R & 5'-CTCGACTTGGGATCCATATTTT-3 & & $\mathrm{C} / \mathrm{CGG}\left(37^{\circ} \mathrm{C}\right)$ & \\
\hline & $\begin{array}{c}\text { exon } 21 \\
\text { (3'UTR region) }\end{array}$ & IGF1Re21F & 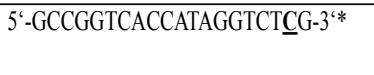 & \multirow[t]{2}{*}{$163 \mathrm{bp}$} & TaqI & \multirow[t]{2}{*}{ ACRS-PCR } \\
\hline & rs41960562 & IGF1Re21R & $5^{6}$-AGTGGGGGTTTTGGCAGAAT-3 & & & \\
\hline
\end{tabular}

\footnotetext{
* sequence introduces a $\mathrm{C}$ instead of the native $\mathrm{T}$
} 
$Y_{i j k l m}=\mu+G_{i}+S_{j}+B S_{k}+b\left(x_{l}-A\right)+\mathrm{SE}_{\mathrm{m}}{ }^{+} e_{i j k l m}$

Where: $1, \ldots 4) ; S_{j}$ - random effect of a sire $\left(\mathrm{j}_{1}=1, \ldots 40 ; \mathrm{j}_{2}=1, \ldots 42\right.$, respectively); $B S_{k}$ - effect of birth season $(\mathrm{k}=1, \ldots 4) ;$ $b$ - linear regression coefficient for age of $1^{\text {st }}$ calving; $x_{l}$ - age of $1^{\text {st }}$ calving of $l$ cow; $A$ - mean age of $1^{\text {st }}$ calving; $\mathrm{SE}_{\mathrm{m}}-\operatorname{sex}(\mathrm{m}=1,2) ; e_{i j k l m}-$ random error.

The analysis included only two first calvings of cows (each calving was analysed separately). Among the whole herd, only animals from single pregnancies were taken into consideration.

\section{Results}

The body weight of calves at birth was optimal for calves of the Montbeliarde breed (compliance with PFCB and DF 2014), which may be partly the result of proper maintenance conditions and feeding of cows. Analysed traits could be affected by different factors, such as the maternal genotype, paternal genotype, sex of their offspring, season of calving, and age at first calving; therefore, these factors are included in the statistical model. The analysis found no paternal and calving season effect on the body weight of calves regardless of the order of calving. The study also took into account the age of cows at first calving due to the fact that early calving cows may have a lower weight, which may be indirectly linked with the birth weight of calves from the first calving. However, because of lack of data regarding the weight of cows at each calving in heifers - cows' cards form, this supposition was not statistically confirmed in this study either. The present analysis also took into account the sex of calves and found a highly significant effect on the body weight $(P<0.01 ; \mathrm{F}$-values ranged from 10.25 to 18.08), where male calves were about $1.2 \mathrm{~kg}\left(1^{\text {st }}\right.$ calving $)$ and $1.5 \mathrm{~kg}\left(2^{\text {nd }}\right.$ calving $)$ heavier. The other significant factor was the maternal genotype.

Genotypes and allele frequencies of the analysed herd of cows are given in Table 2. None of the animals had the $T T$ genotype at the IGF1R/TaiI locus. The most frequent was the $C C$ genotype (0.8957). Three genotypes were identified at the second locus (IGFIR/MspI). The most frequent was the $G G$ genotype (0.7730), followed by the $A G$ genotype $(0.1288)$ and the least common $A A$ genotype (0.0982). At the $I G F 1 R / T a q \mathrm{I}$ locus, the most frequent were animals carrying the $G G$ genotype ( 0.5828 ), while the $A A$ genotype was the rarest of all ( 0.1963$)$. Tables 2 and 3 present the average weight of calves in the first and second calving, in relation to the $I G F 1 R$ genotypes and their combinations. The average birth weight of calves from the first and second calving, whose mothers had the $C C$ genotype at the IGF1R/TaiI locus was significantly higher (1.40 kg $P<0.05,+3.81 \mathrm{~kg} P<0.01$, respectively) in comparison with $C T$.

Certain correlation was found in the case of the IGF1R/MspI locus. The average body weight of calves regardless of the calving order was the highest in animals with the maternal $G G$ genotype, and the lowest in calves from mothers of the $A A$ genotype calving for the first time and of the $A G$ genotype in the case of the second calving. Significant differences $(P<0.05)$ in the body weight of calves after the first calving were found between cows with $G G$ and $A A$ genotypes $(+1.2 \mathrm{~kg})$. Significant differences were also reported $(P<0.01)$ after the second calving between the body weight of calves from mothers with $G G$ and $A G$ genotypes $(+2.37 \mathrm{~kg})$ as well as $G G$ and $A A$ genotypes $(+2.22 \mathrm{~kg})$.

Similar trends were found at the third analysed polymorphism, IGF1R/TaqI. Cows with the $A A$ genotype calving for the first time gave birth to heavier calves than cows with the $A G(+1.35 \mathrm{~kg}, P<0.05)$ and $G G$ genotypes $(+1.83 \mathrm{~kg}, P<0.01)$. There were no significant differences found in the next calving in the body weight of new-born calves. Frequencies of genotype combinations were also analysed in order to confirm the significance of the previously observed association. A total of 14 combinations was compared, from which due to low frequency $(\mathrm{n}<10)$ only 4 were used for calculations (Table 3$)$, wherein the most common combination of genotypes was $C C / G G / G G$. 
Table 2. Mean body weight of calves from the first and second calving in relation to the genotype of the mother (cow) (standard errors in parentheses).

\begin{tabular}{|c|c|c|c|c|c|c|}
\hline Polymorphisms & Genotype & $\mathrm{n}$ & Genotype frequency & Allele frequency & $\begin{array}{l}\text { BWT at } 1^{\text {st }} \\
\text { calving }(\mathrm{kg})\end{array}$ & $\begin{array}{l}\text { BWT at } 2^{\text {nd }} \\
\text { calving }(\mathrm{kg})\end{array}$ \\
\hline \multirow{3}{*}{$I G F 1 R / T a i \mathrm{I}$} & $C C$ & 146 & 0.8957 & \multirow{2}{*}{$\begin{array}{l}\mathrm{C}=0.95 \\
\mathrm{~T}=0.05\end{array}$} & $\begin{array}{r}35.2^{\mathrm{a}} \\
(0.18)\end{array}$ & $\begin{array}{r}35.34^{\mathrm{A}} \\
(0.16)\end{array}$ \\
\hline & $C T$ & 17 & 0.1043 & & $\begin{array}{r}33.8^{\mathrm{a}} \\
(0.62)\end{array}$ & $\begin{array}{l}31.53^{\mathrm{A}} \\
(0.19)\end{array}$ \\
\hline & Total & 163 & 1.0000 & & & \\
\hline \multirow[t]{4}{*}{$I G F 1 R / M s p I$} & $G G$ & 126 & 0.7730 & \multirow{3}{*}{$\begin{array}{l}A=0.16 \\
G=0.84\end{array}$} & $\begin{array}{l}35.26^{\mathrm{a}} \\
(0.18) \\
\end{array}$ & $\begin{array}{r}35.47^{\mathrm{AB}} \\
(0.18) \\
\end{array}$ \\
\hline & $A G$ & 21 & 0.1288 & & $\begin{array}{l}34.29 \\
(0.60)\end{array}$ & $\begin{array}{c}33.10^{\mathrm{A}} \\
(0.39)\end{array}$ \\
\hline & $A A$ & 16 & 0.0982 & & $\begin{array}{l}34.06^{\mathrm{a}} \\
(0.63)\end{array}$ & $\begin{array}{l}33.25^{\mathrm{B}} \\
(0.45)\end{array}$ \\
\hline & Total & 163 & 1.0000 & & & \\
\hline \multirow[t]{4}{*}{ IGF1R/TaqI } & $A A$ & 32 & 0.1963 & \multirow{3}{*}{$\begin{array}{l}A=0.31 \\
G=0.69\end{array}$} & $\begin{array}{r}36.38^{\mathrm{Aa}} \\
(0.38)\end{array}$ & $\begin{array}{l}35.03 \\
(0.43)\end{array}$ \\
\hline & $A G$ & 36 & 0.2209 & & $\begin{array}{l}35.03^{\mathrm{a}} \\
(0.33)\end{array}$ & $\begin{array}{l}34.94 \\
(0.38)\end{array}$ \\
\hline & $G G$ & 95 & 0.5828 & & $\begin{array}{l}34.55^{\mathrm{A}} \\
(0.22)\end{array}$ & $\begin{array}{l}34.91 \\
(0.22)\end{array}$ \\
\hline & Total & 163 & 1.0000 & & & \\
\hline
\end{tabular}

Mean values within a column bearing the same superscript differ significantly at $P<0.01$ (upper case superscripts) and $P<0.05$ (lower case superscripts); BWT - birth weight

Table 3. Combined genotypes of the IGF1R gene.

\begin{tabular}{|c|c|c|c|c|c|}
\hline Polymorphisms & $\begin{array}{c}\text { Combined } \\
\text { genotypes* }\end{array}$ & $\mathrm{n}$ & $\mathrm{f}$ & $\begin{array}{l}\text { BWT at } 1^{\text {st }} \\
\text { calving }(\mathrm{kg})\end{array}$ & $\begin{array}{l}\text { BWT at } 2^{\text {nd }} \\
\text { calving }(\mathrm{kg})\end{array}$ \\
\hline & $C C / G G / G G$ & 79 & 0.4847 & $\begin{array}{l}34.86^{\mathrm{A}} \\
(0.21)\end{array}$ & $\begin{array}{l}35.48^{\mathrm{D}} \\
(0.18)\end{array}$ \\
\hline$I G F 1 R$ & $C C / G G / A G$ & 24 & 0.1473 & $\begin{array}{l}35.14^{\mathrm{B}} \\
(0.36)\end{array}$ & $\begin{array}{l}36.21^{\mathrm{E}} \\
(0.32)\end{array}$ \\
\hline \multirow[t]{2}{*}{ TaiI/MspI/TaqI } & $C C / G G / A A$ & 13 & 0.0798 & $\begin{array}{l}37.92^{\mathrm{ABC}} \\
(0.40)\end{array}$ & $\begin{array}{l}37.00^{\mathrm{DEF}} \\
(0.44)\end{array}$ \\
\hline & $C C / A A / A A$ & 11 & 0.0675 & $\begin{array}{l}35.09^{\mathrm{C}} \\
(0.64)\end{array}$ & $\begin{array}{l}34.27^{\mathrm{F}} \\
(0.47)\end{array}$ \\
\hline
\end{tabular}

Mean values within columns bearing the same superscript differ significantly at $P \leq 0.01$.

BWT - birth weight; $\mathrm{n}$ - number of individuals; $\mathrm{f}$ - frequency

* only four combined genotypes $(\mathrm{n}>10)$ among all possible combinations were taken into account

Analysing individual genotypes in the examined polymorphic loci, hypothetically it could be expected that cows with the combination of $C C / G G / A A$ regardless of the order of calving will give birth to progeny with the highest birth weight. This was confirmed statistically, because cows carrying such a combination always gave birth to progeny of the highest birth weight, independently of the order of calving $(P<0.01)$. 


\section{Discussion}

Proper growth and development of calves is affected by both genetic and environmental factors (Szewczuk et al. 2013a). According to many authors (Meyer et al. 2001; Johanson and Berger 2003), the order of calving significantly affects the weight of the calf at birth. This is mainly because of the competition between the development of their own body and an increase of foetal weight, especially in the case of primiparous cows (Meyer et al. 2000; Kocak et al. 2007). These results could not be fully confirmed in the present studies, as the birth weight of calves did not necessarily increase with the next calving in every case (Tables 2 and 3). Perhaps during the following calvings the differences in calf weights at birth would become more apparent. Far-reaching conclusions cannot be drawn due to the lack of consistent and unambiguous statements supporting this assumption in the available literature. The body weight of the cow is associated with the stature, and has a direct impact on the course of parturition (larger cows tend to have a larger area of pelvic canal) and the weight of the calf at birth, which next to nutrition has a significant impact on daily gains of calves during rearing (Nogalski and Mordas 2012). The pelvis size does not increase together with the increase of the cow's weight but is rather constant and cannot be adjusted by environmental conditions (Holm et al. 2014). Therefore, selecting an appropriate time of the first fertilization may probably be important, and according to Wathes et al. (2014) it can also affect the length of maintaining cows in the herd and reduce the possibility of conception complications. From the perspective of a breeder it is a very important moment, because the occurrence of problematic conceptions in cows, particularly in heifers, increases perinatal mortality of calves (Heins et al. 2006) and adversely affects the subsequent viability of calves (Story et al. 2000), reduces the cows' productivity and deteriorates their health.

Olson et al. (2009), Kocak et al. (2007), Kaygisiz et al. (2012) and Szewczuk et al. (2013a) believe that the factor responsible for variation in the body weight of calves at birth and the subsequent growth rate is the animals' sex. Bull calves are generally born heavier than heifer calves and grow faster during rearing (Szewczuk et al. 2013b). Differences in body weights of calves of different sexes at birth are partly due to the fact that pregnancies with a male foetus are usually about 1-2 days longer. In the present analysis the sex of the calves had a highly significant effect on the body weight.

Cows calving twins usually have smaller calves. The study of Dhaka et al. (2013) demonstrated that heifer and bull calves from twin pregnancies and first calving cows had lower birth weights compared to the bull calves, calves from single pregnancies, and calves from successive calvings, respectively. Similar observations were made by Szewczuk et al. (2013b), although these authors did not analyse the impact of sex on the calf's birth weight, while including sex distribution in the 50:50 proportion. The lack of multiple pregnancies in the present study did not allow to compare the results.

Statistical analysis also included the season of birth of the calf. According to some authors, the season of birth of calves has a significant impact on their body weight at birth, survival, and higher or lower weight gains in the following few months of life (Kocak et al. 2007; Chang'a et al. 2012; Szewczuk et al. 2013b). Kocak et al. (2007) reported that calves born in the spring had the highest body weight at birth, which might result from lower temperatures (at that time of year) and good availability of feed in the last months of pregnancies of the mothers. The present analysis found no such effect.

Several recent studies have reported on the Quantitative Trait Loci (QTL) associated with birth weight (Cole et al. 2014). Casas et al. (2003) identified QTL for birth weight in the very proximal region of BTA21 in crossbreeds. Some calving ease and meat production markers have been identified on BTA21 in German Fleckvieh (Pausch et al. 2011). Therefore, some studies were conducted to identify polymorphisms within the $G H, G H R$, 
and IGF1 genes to study the association of these polymorphisms with growth traits (Ge et al. 2003; Szewczuk et al. 2013a). Only one study applies to SNPs within the IGF1R gene and no significant differences were detected between each polymorphic sites or the combined genotypes and birth weight in the Angus cattle (Szewczuk et al. 2013c). The maternal genotype can have a significant impact on the body weight of calves at birth (Dhakal et al. 2013), which was also demonstrated in the present study. Expression of insulin like growth factors and their receptors in foetal skeletal muscles is dependent on the maternal diet (Gonzalez et al. 2013). It was found that foetal somatotropic axis is regulated by the supply of nutrients to the foetus (Holt 2002) and this function mutually interacts between maternal nutrients and foetal maturity (Wallace et al. 2005). Postnatal muscle growth was a result of the hypertrophy of existing myocytes, or the activation of satellite cells. These processes are dependent on the interaction between IGF and its receptor (Chargè and Rudnicki 2004). Due to lack of manuscripts in the area of expression and polymorphism of the bovine $I G F 1 R$ gene, it is impossible to compare the results not only with regard to the dual-purpose Montbeliarde breed or classical dairy cattle but even to beef breeds.

In view of the substantial role of the IGF-I/IGF-IR system in the growth and development of the mammary gland and the muscle tissue, the determination of the structure and location of the polymorphic sites in the gene encoding the receptor for insulin-like growth factor I $(I G F 1 R)$ can allow for a potential selection in terms of the preferred polymorphic variants for the traits of interest.

\section{References}

Borkowska D, Januś E 2010: Analysis of the influence of chosen factors on somatic cell count in milk of Montbeliarde cows. Acta Sci Pol 9: 39-46

Casas E, Shackelford SD, Keele JW, Koohmaraie M, Smith TPL, Stone RT 2003: Detection of quantitative trait loci for growth and carcass composition in cattle. J Anim Sci 81: 2976-2983

Chang'a JS, Løken T, Mdegela RH, Reksen O 2012: Factors associated with body weight attainment in calves on small holder dairy farms in Tanzania. Open J Vet Med 2: 66-73

Chargé SB, Rudnicki MA 2004: Cellular and molecular regulation of muscle regeneration. Physiol Rev 84: 209-238

Dhakal K, Maltecca C, Cassady JP, Baloche G, Williams CM, Washburn SP 2013: Calf birth weight, gestation length, calving ease, and neonatal calf mortality in Holstein, Jersey, and crossbred cows in a pasture system. J Dairy Sci 96: 690-698

Ge W, Davis ME, Hines HC, Irvin KM, Simmen RCM 2003: Association of single nucleotide polymorphisms in the growth hormone and growth hormone receptor genes with blood serum insulin-like growth factor I concentration and growth traits in Angus cattle. J Anim Sci 81: 641-648

Gonzalez JM, Camacho LE, Ebarb SM, Swanson KC, Vonnahm KA, Stelzleni AM, Johnson SE 2013: Realimentation of nutrient restricted pregnant beef cows supports compensatory fetal muscle growth J Anim Sci 91: 4797-4806

Gołębiewski M, Brzozowski P 2008: Comparison of dairy performance of Montbeliarde and Black-and-White cows housed in the same environmental conditions. Ann Anim Sci 8: 3-11

Heins B, Heins J, Hansen LB, Seykora AJ 2006: Calving difficulty and stillbirths of pure Holsteins versus crossbreds of Holstein with Normande, Montbeliarde, and Scandinavian Red. J Dairy Sci 89: 2805-2810

Holm DE, Webb EC, Thompson PN 2014: A new application of pelvis area data as culling tool to aid in the management of dystocia in heifers. J Anim Sci 92: 2296-2303

Holt RI 2002: Fetal programming of the growth hormone-insulin-like growth factor axis. Trends Endocrin Met 13: $392-397$

Johanson JM, Berger PJ 2003: Birth weight as a predictor of calving ease and perinatal mortality in Holstein cattle. J Dairy Sci 86: 3745-3755

Kaygisiz A, Bakir G, Yilmaz I 2012: Genetic parameters for direct and maternal effects and an estimation of breeding values for birth weight of Holstein Friesian calves. Bulg J Agric Sci 18: 117-124

Koçak S, Teker M, Özbeyaz C, Yüceer B 2007: Environmental and genetic effects on birth weight and survival rate in Holstein calves. Turk J Vet Anim Sci 31: 241-246

Macias H, Hinck L 2012: Mammary gland development. Wires Dev Biol 1: 533-557

Meyer CL, Berger PJ, Koehler KJ 2000: Interactions among factors affecting stillbirth in Holstein cattle in the United States. J Dairy Sci 83: 2657-2663 
Meyer CL, Berger PJ, Koehler KJ, Thompson JR, Sattler CG 2001: Phenotypic trends in incidence of stillbirth for Holsteins in the United States. J Dairy Sci 84: 515-523

Nogalski Z, Mordas W 2012: Pelvic parameters in Holstein-Friesian and Jersey heifers in relation to their calving. Pak Vet J 32: 507-510

Olson KM, Cassell BG, McAllister AJ, Washburn SP 2009: Dystocia, stillbirth, gestation length, and birth weight in Holstein, Jersey, and reciprocal crosses from a planned experiment. J Dairy Sci 92: 6167-6175

Pausch HK, Flisikowski S, Jung S, Emmerling R, Edel C, Götz KU, Fries R 2011: Genome-wide association study identifies two major loci affecting calving ease and growth-related traits in cattle. Genetics 187: 289-297

Pertoldi C, Purfield DC, Berg P, Jensen TH, Bach OS, Vingborg R, Kristensen TN 2014: Genetic characterization of a herd of the endangered Danish Jutland cattle. J Anim Sci 92: 2372-2376

Polish Federation of Cattle Breeders and Dairy Farmers (PFCB and DF) 2014: The Results of

Milk Recording in Poland in 2013 [in Polish]. Wydaw PFHBiPM, Warszawa, 112 p.

Story CE, Rasby RJ, Clark RT, Milton CT 2000: Age of calf at weaning of spring-calving beef cows and the effect on cow and calf performance and production economics. J Anim Sci 78: 1403-1413

Szewczuk M, Bajurna M, Zych S, Kruszyński W 2013a: Association of insulin-like growth factor I gene polymorphisms (IGF1/TasI and IGF1/SnaBI) with the growth and subsequent milk yield of Polish HolsteinFriesian heifers. Czech J Anim Sci 58: 404-411

Szewczuk M, Borcz A, Chociłowicz E, Czerniawska-Piątkowska E 2013b: Comparison of milk production between Black-and-White Holstein-Friesian cows imported from Sweden and domestic peers. Acta Sci Pol 12: $57-68$

Szewczuk M, Zych S, Wójcik J, Czerniawska-Piątkowska E 2013c: Association of two SNPs in the coding region of the insulin-like growth factor 1 receptor (IGF1R) gene with growth-related traits in Angus cattle. J App Genet 54: 305-308

Trela J 2003: Acclimation and some production indicators of Montbeliarde cattle in Poland [in Polish]. Zesz Nauk Przeg Hod 67: 67-77

Wallace JM, Regnault TRH, Limesand SW, Hay WWJ, Anthony RV 2005: Investigating the causes of low birth weight in contrasting ovine paradigms. J Physiol 565: 19-26

Wathes DC, Pollott GE, Johnson KF, Richardson H, Cooke JS 2014: Heifer fertility and carry over consequences for life time production in dairy and beef cattle. Animal 3: 1-14 